\title{
Kikkerten for det blinde øje
}

\section{Kristina Siig}

\section{Folkeretten giver staterne rig mulighed for at rets- forfølge pirater i Adenbugten. Så når staterne i vidt omfang alligevel sætter tilfangetagne pirater på fri fod, har det andre årsager}

Den 5. februar i år kunne den noget betuttede verdenspresse høre den nyvalgte leder for African Union, Muammar Gaddafi, udtale, at de somaliske pirater langt fra var pirater. Tværtimod handlede de i selvforsvar mod grådige vestlige nationer, som illegalt havde invaderet og eksploiteret Somalias territorialfarvand. Gaddafi sluttede med vanlig sans for en god overskrift af med: "Det er ikke sørøveri... de forsvarer de somaliske børns ret til at få mad."

Men lad os starte med at slå fast, at moderne pirateri ikke er et nyt fænomen. Det har i lang tid været et problem ud for Nigerias kyst og ikke mindst i Fjernøsten. De snævre farvande omkring Malaysia og Indonesien var fulde af pirater, før tsunamien slog hele piratflåden til pindebrænde - samt må man formode tog livet af en god del af 'arbejdsstyrken'. Det er heller ikke nyt, at rederibranchen tager problemet op og forsøger at imødegå det. Nej, det nye er, at der nu er opstået en global lydhørhed over for problemet, og at piraterne i det hele taget er blevet et kort, der kan spilles i international politik.

I dansk indenrigspolitik blev kortet for alvor spillet i begyndelsen af 2008. Den 15. januar 2008 fremlagde udenrigsministeren således "Forslag til folketingsbeslutning om dansk deltagelse med sømilitært bidrag til styrkelse af den maritime sikkerhed ved Afrikas Horn". Forslaget skulle ses i lyset af, at det danske fragtskib Danica White i sommeren 2007 blev tilbageholdt i 83 dage i Adenbugten. Ifølge beslutningsforslaget skulle "et flådefartøj af Absalon-klassen" udsendes til deltagelse i Task Force 150.

Task Force 150 har folkeretlig hjemmel i FN's Sikkerhedsråds resolutioner nr. 1368 og nr. 1373. Resolutionerne er udstedt henholdsvis 
den 12. og den 28. september 2001, og vedrører ikke overraskende bekæmpelse af terrorisme samt finansieringen af terrorisme i lyset af 11 . september.

Der henvistes i beslutningsforslaget yderligere til FN's Sikkerhedsråds resolution nr. 1772 af 2007 om situationen i Somalia. Resolutionen handler generelt om den ulykkelige situation på fastlandet i Somalia, men har en enkelt passus, hvorefter Sikkerhedsrådet bl.a. opfordrer stater, som har flådefartøjer i internationalt farvand i nærheden, til at være opmærksomme på pirateri, samt til at tage skridt til at beskytte handelsskibe og skibe, der transporterer nødhjælp 'i overensstemmelse med folkeretten.' Resolutionen giver således ikke yderligere beføjelser til indgriben, end der findes i forvejen.

Folkeretten giver dog allerede ret vidtgående beføjelser til at forfølge pirater. Efter FN's Havretskonvention, art. 100, er alle stater således forpligtet til "i størst muligt omfang [at] samarbejde om bekæmpelse af sørøveri på det åbne hav eller på andre steder uden for nogen stats jurisdiktion."

Derudover kan enhver stat inden for det samme geografiske område opbringe sørøverskibe, samt tilbageholde piraterne og beslaglægge deres 'arbejdsredskaber'. Det fremgår yderligere af Havretskonventionen art. 105, at domstolene i den stat, der har foretaget opbringningen el- ler tilbageholdelsen, kan straffe piraterne.

\section{Ikke terrorister}

De somaliske pirater er ikke terrorister - for at en skibskapring er terrorisme, kræves det, at kapringen foretages for at opnå et veldefineret politisk mål eller i det mindste for at sprede skræk og rædsel og generelt virke destabiliserende. De somaliske pirater er derimod 'forretningsmænd' og vil simpelthen have penge. På den baggrund virker det måske en smule skæut at sende Absalon til Task Force 150 eksplicit med piratbekæmpelse for øje, sådan som Folketinget gjorde med beslutningens vedtagelse. Juridisk er det dog ikke problematisk, da man ifølge ovenstående ikke behøver et FNmandat for at sende et dansk krigsskib til Adenbugten på piratjagt - så længe man er tilfreds med at tage de pirater, man kan fange i internationalt farvand.

En mere håndfast hjemmel til at gribe ind kom den 2. juni 2008. Sikkerhedsrådets resolution nr. 1816 gav, efter anmodning eller samtykke (det er lidt uklart, om det er det ene eller det andet), fra den somaliske overgangsregering, TFG, de styrker, der samarbejdede med TFG ret til de næste 6 måneder at forfølge piraterne ind i somalisk territorialfarvand.

Flådeenhederne fik for så vidt ikke nye typer beføjelser ud over 
det, der fulgte af Havretskonventionen, men de fik nu lov at udøve dem også inden for somalisk søterritorium. Kommissoriet blev forlænget med 12 måneder den 2. december 2008. Endelig fik "de stater, der samarbejdede med TFG", den 16. december 2008 i resolution nr. 1851 ret til at tage "all necessary measures that are appropriate in Somalia", dvs. også deltage i landbaserede aktioner på stort set hvilken som helst måde, dog med respekt af humanitær ret og menneskerettighederne.

Resolution 1851 kan dårligt ses som andet end en fuldstændig ophævelse af Somalias suverænitet, når det drejer sig om pirater. Sikkerhedsrådet henleder da også flere gange opmærksomheden på, at resolutionen blev udstedt, fordi TFG i brev af 9. december 2008 havde samtykket til den. Man kunne i den forbindelse overveje, om TFG har så meget kontrol over, hvad der foregår i Somalia, at der reelt set er nogen suverænitet at give afkald på. Men TFG accepteres om ikke andet af FN som Somalias regering, så folkeretligt holder det vand.

\section{Piraterne går fri}

Man kunne mene, at resolution nr. 1851 havde ladet vente for længe på sig. Frankrig havde fx for længst mistet tålmodigheden. I april 2008 havde franske specialstyrker således pågrebet pirater ved en landbaseret operation inde i Somalia i forbindel- se med frigivelsen af lystyachten 'Le Ponant'.

Dette skete så vidt ses uden reel folkeretlig hjemmel, men nok med en begrundet forventning om, at ingen ville beklage sig. Den daværende somaliske premierminister, M. Nur Hassan Hussein udtalte kort efter, den 20. april 2008, i en pressemeddelelse: "The French forces arrested six Somali pirates and took them to France to face justice. We encourage such steps by the French. The Somali government asks the international community to take action against piracy".

Udtalelsen gav dog ikke folkeretlig hjemmel til Frankrigs indgriben på det givne tidspunkt, hvilket piraternes beskikkede forsvarere siden har haft megen sjov ud af. For godt nok kan piraterne retsforfølges i Frankrig, men de synes umiddelbart at være ulovligt tilfangetaget og dernæst tilbageholdt, for at denne retsforfølgelse har kunnet finde sted. Efter resolutionens vedtagelse vil fremtidige aktioner af denne type folkeretligt set være berettigede. Det er dog ikke en selvfølgelighed, at tilstedeværelsen af en folkeretlig hjemmel til magtanvendelse fører til, at de formodede pirater bringes for en domstol. Dette er Sikkerhedsrådet opmærksom på. Som det siges i præamblen til resolution 1851:

"Noting with concern that the lack of capacity, domestic legislation, and clarity about how to dispose of pirates after their capture, has hindered more robust international action against the pirates off 
the coast of Somalia and in some cases led to pirates being released without facing justice, and reiterating that the 1988 Convention for the Suppression of Unlawful Acts Against the Safety of Maritime Navigation (SUA Convention) provides for parties to create criminal offences, establish jurisdiction, and accept delivery of persons responsible for or suspected of seizing or exercising control over a ship by force or threat thereof or any other form of intimidation ..."

I løbet af efteråret 2008 havde det nemlig vist sig, at Task Force 150 trods vidtrækkende $\mathrm{FN}$-mandater reelt arbejdede i et delvist retstomt rum for så vidt angik retsforfølgningen af piraterne.

Det burde ikke være sådan. Regelværket til international retsforfølgelse af pirater er allerede til stede. Ud over reglerne i Havretskonventionen, der giver staterne ret til brug af fysisk magt, samt ret til at strafforfølge enhver pirat, de lovligt har fået fat i, har langt de fleste stater undertegnet SUA-konventionen. Efter den er staterne forpligtede til at gøre pirathandlinger strafbare, samt til at skabe international straffejurisdiktion for pirathandlinger begået af egne statsborgere, i eget territorialfarvand eller mod egne skibe. Der eksisterer således teoretisk set et vandtæt system, der burde medføre, at de pirater, det lykkes at tilbageholde, også vil blive bragt for en domstol. Men systemet havde vist sig at være mildest talt utæt i praksis.

Efter SUA-konventionen skal So- malia tage imod somaliske pirater samt pirater af en hvilken som helst nationalitet, der pågribes i somalisk territorialfarvand. Men dels er Somalia en af de få stater, der ikke har underskrevet SUA-konventionen, dels har sammenbruddet af en reel fungerende stat i Somalia i det hele taget gjort dette urealistisk.

På den ene side kan man ikke være sikker på, at de mistænkte ikke bare bliver sluppet fri med et skuldertræk, på den anden side kan det være, de bliver udsat for en straf, der ikke er i overensstemmelse med forpligtelsen til ikke at udlevere eller frigive folk til $\mathrm{fx}$ tortur. Denne del af systemet i SUA er med andre ord brudt sammen i forhold til piraterne i Adenbugten.

Problemet blev i dansk sammenhæng første gang sat på spidsen, da Absalon den 23. september 2008 måtte landsætte 10 formodede pirater ved at 'frigive dem over stranden', da man frygtede, de ville lide overlast, hvis de blev officielt overgivet til de somaliske myndigheder.

Modsat dette har Frankrig, som en reaktion på de dårlige erfaringer med at tage piraterne med hjem, fundet det mest hensigtsmæssigt at udlevere de senest tilfangetagne pirater til Somalia mod 'diplomatiske forsikringer' om, at ting nok skal gå ordentligt for sig. En anden variant af problemet opstod, da Absalon i begyndelsen af december 2008 afleverede syv skibbrudne somaliske 'formodede pirater' til myndighe- 
derne i Yemen i overensstemmelse med de internationale regler om skibbrudne - men så vidt ses ikke $\mathrm{i}$ overensstemmelse med reglerne for overgivelse af mistænkte i straffesager. Såfremt man havde haft en reel forventning om, at overgivelse til somaliske myndigheder ville give mening, havde ‘udleveringen' til Yemen måske kunnet undgås.

Selv i de tilfælde, hvor piraterne angriber skibe, der tilhører velfungerende stater, som har tiltrådt SUAkonventionen, har det ikke været let at få staterne til at tage imod piraterne til retsforfølgelse. Således måtte Danmark i januar 2009 vride armen meget langt om på hollænderne for at få dem til at modtage de pirater, Absalon havde forhindret $\mathrm{i}$ at kapre et hollandsk skib. Grunden til modvillighed havde ikke noget med folkeret at gøre. Den var indenrigspolitisk.

\section{Indenrigspolitiske forviklinger}

I stedet for at pege fingre ad hollændernes fodslæberi kunne vi måske diskutere vores eget.

Ud over forpligtelserne efter SUAkonventionen, tillader Havretskonventionens art. 105 netop, at vi retsforfølger enhver pirat, vi lovligt har tilbageholdt. Men Danmark har som mange andre stater - ikke udmøntet denne mulighed i nationale strafferetlige hjemmelsbestemmelser. Vi har folkeretlig hjemmel til at tilfangetage og tilbageholde pirater.
Vi har derudover strafferetlig hjemmel i straffelovens $\S 8$ b, stk. 1, til at straffe piraterne, hvis de efterfølgende tilfældigvis skulle befinde sig $\mathrm{i}$ Danmark. Vi mangler bare - som franskmændene - en hjemmel til at transportere dem fra Adenbugten til Danmark. Det bedste bud på en eksisterende hjemmel ville formentlig være, at pligten til at samarbejde om bekæmpelse af pirateri i Havretskonventionens art. 100, sammenholdt med retten til at strafforfølge i konventionens art. 105 skulle fortolkes som en pligt til at retsforfølge, hvilket ville give national dansk straffehjemmel ifølge straffelovens § 8 , stk. 1. nr. 5. Men når henses til kravet om 'ingen straf uden lov', vil en fortolkning som denne næppe blive accepteret af domstolene.

Hvorfor har man så ikke lavet straffeloven om? I stedet for at være et ufrivilligt skoleeksempel på dårlig spin hen over efteråret 2008 kunne forsvarsministeren have fremstået som en rederivenlig fremskridtets mand, hvilket aldrig er helt dumt i dansk politik.

Heller ikke oppositionen ønskede at lægge billet ind på ændringen. Selv da det kom frem, at ministeren havde været påfaldende tavs om dels, at Danmark ikke havde bilaterale aftaler om udlevering til afsoning i regionen, dels at en meget lille ændring af straffeloven ville kunne løse problemet for fremtiden, kom den kun med et par små fork $\varnothing$ lede 'for-dårligt'-pip. 
Den eneste forklaring, der giver mening, er, at ingen reelt ønsker de formodede pirater til Danmark, fordi man som følge af forbuddet mod at udvise til krigszoner og tortur ikke vil kunne slippe af med dem igen. Med mindre situationen ændrer sig drastisk i Somalia må man derfor antage, at piraterne i kortere eller længere tid efter endt afsoning i et dansk fængsel må være på tålt ophold i Danmark - hvilket af alle parter i det politiske spektrum anses for særdeles uhensigtsmæssigt.

Beslutningen om ikke at tiltage sig straffejurisdiktion på dette område er naturligvis først og fremmest politisk. Bortset fra det vil strafforfølgning i Danmark dog også juridisk set, på grund af de senfølger, det må antages at have, fremstå som uforholdsmæssig. Herved kommer en sådan potentiel regulering ikke bare i konflikt med en almindelig forståelse af hensigtsmæssighed. Den bliver juridisk illegitim. Ikke at tiltage sig en magtbeføjelse i en situation, hvor man ellers er juridisk berettiget til det, kan således sagtens være den juridisk korrekte løsning.

Men selvom manglen på hensigtsmæssighed er en god grund til ikke at tiltage sig en ret i en juridisk gråzone, betyder det ikke, at det også er en tilstrækkelig grund til at frasige sig en pligt, hvor den folkeretlige regulering er klar.

Ikke mindst efter, at Danmark pressede hollænderne til at modtage 'deres' pirater, må vi være parat til at modtage 'vore', hvis det skulle lykkes nogen at få fat i dem. Så man bør være forberedt på, at nogle af piraterne med tiden ender for en dansk domstol, med de konsekvenser, det måtte have.

\section{Første skridt mod løsninger}

Uanset hvad man måtte mene om fx 'Tuneserloven' og om tidshorisonten for en løsning på situationen i Somalia, må man spørge sig selv, om det er hensigtsmæssigt, at somaliske pirater sendes rundt omkring til alverdens søfartsnationer til domfældelse og afsoning.

Andre løsningsmodeller har som nok bekendt været diskuteret. Det er lykkedes for visse stater at indgå bilaterale aftaler med Kenya om, at piraterne kan bringes for en domstol der, og således holde piraterne $\mathrm{i}$ regionen. Danmark har derudover foreslået Sikkerhedsrådet, at der nedsættes et hold af eksperter, som kan hjælpe med retsforfølgningen.

Mere vidtgående er dannelsen af en 'international sørøverdomstol' blevet nævnt. Succesen med at nedsætte internationale konfliktløsningsorganer i Rwanda og Eksjugoslavien har måske skabt en forventning om, at der nedsættes internationale domstole, når et statssammenbrud medfører lovovertrædelser.

Uden at negligere, at kapringerne har været dybt traumatiske for de tilbageholdte søfolk, må man nok erkende, at de somaliske pirater ikke 
er i den samme liga som Rwandas og Eksjugoslaviens folkemordere, og at nedsættelse af en international straffedomstol måske er en overreaktion. Eksistensen af en straffedomstol løser heller ikke automatisk afsonings- og repatrieringsproblemet. Gode, hensigtsmæssige, juridiske løsninger ligger med andre ord ikke lige for.

På den baggrund fremstår det som meget positivt, at mange af de regionale kyststater nu har indgået en aftale - Code of Conduct - der skal gøre det lettere for staterne at samarbejde om ved fysisk magtudøvelse at holde piraterne i skak. Det betyder ikke, at en international judiciel løsning har spillet fallit. Men i forhold til piraterne i Adenbugten forekommer den bare ikke specielt hensigtsmæssig.

Hvis vi afslutningsvist vender tilbage til Muammar Gaddafi, er han citeret for i talen af 5. februar 2008 yderligere at have sagt følgende: "De europæiske, amerikanske og kinesiske flådefartøjer trænger sig ind på den suveræene stat Somalias territorium, fordi Afrika ikke har et stærkt og moderne forsvar, som kan slå dem tilbage."

En sådan udtalelse er formentlig mest ment som løftestang til Gadaffis eget politiske projekt, nemlig et forenet Afrika, men giver dog anledning til at stoppe op. Er der underliggende, uudtalte bevæggrunde til, at verdenssamfundet pludselig har investeret i piratbekæmpelse? Har koalitionen blot udnyttet magtvakuummet i kølvandet på Somalias sammenbrud til at opnå en uberettiget, geopolitisk fordel?

Svaret herpå må være klart nej, men fraværet af en reel statsmagt $i$ Somalia gør naturligvis aktionen nemmere at forsvare, og den medvind, projektet har haft, må have sin forklaring i et eller andet. At FN har brug for et fælles projekt, som alle er enige om berettigelsen af, og som faktisk bliver gennemført, har været nævnt som grund. Det er måske ikke helt ved siden af.

Om FN virkelig har intention om at få has på piratvirksomhed, eller om der blot har været tale om en stort anlagt samarbejds- og feel-goodøvelse, finder vi måske snart ud af. Piraterne i Fjernøsten er nemlig så småt begyndt at røre på sig igen. De er ikke i nærheden af deres 'pre-tsunami'-niveau, men 'erhvervet' synes atter at være i vækst. Det bliver interessant at se, om FN og verdensopinionen vil være lige så villige til at acceptere, at der sendes flådefartøjer på piratjagt til Malaysia eller Indonesien. Og om disse to, overordnet set velfungerende kyststater, $\mathrm{i}$ så fald vil tillade $\mathrm{fx}$ landbaserede operationer, så længe det bare drejer sig om pirater. Formodningen er i begge tilfælde nej.

Kristina Siig er dr. juris og lektor i sø- og transportret ved Juridisk Institut på Syddansk Universitet samt Post Doc. ved Nordisk Institutt for Sjørett i Oslo. 